\title{
Demir Baba : saint et héros des musulmans hétérodoxes en Bulgarie
}

Demir Baba, a Saint and Hero of Heterodox Muslims in Bulgaria

\section{Bojidar Alexiev}

\section{CpenEdition}

Journals

Édition électronique

URL : http://journals.openedition.org/etudesbalkaniques/422

ISSN : 2102-5525

\section{Éditeur}

Association Pierre Belon

\section{Édition imprimée}

Date de publication : 1 janvier 2000

Pagination : $143-156$

ISBN : 2-910860-10-8

ISSN : $1260-2116$

\section{Référence électronique}

Bojidar Alexiev, «Demir Baba : saint et héros des musulmans hétérodoxes en Bulgarie », Études balkaniques [En ligne], 7 | 2000, mis en ligne le 08 avril 2009, consulté le 12 mai 2019. URL : http:// journals.openedition.org/etudesbalkaniques/422

Ce document a été généré automatiquement le 12 mai 2019

Tous droits réservés 


\section{Demir Baba : saint et héros des musulmans hétérodoxes en Bulgarie}

Demir Baba, a Saint and Hero of Heterodox Muslims in Bulgaria

Bojidar Alexiev

\section{RÉSUMÉS}

L'auteur présente les kızılbaş en soulignant leur non-conformisme politique et leur messianisme. Situé dans ce contexte à partir de son vilayetname, Demir Baba fait alors l'objet d'une analyse historique et culturelle.

The author sets out the kızlbaş by emphasizing their non-conformism and messanism. In this context, thanks to his vilayetname, Demir Baba is analyzed in an historical and cultural perspective.

\section{AUTEUR}

\section{BOJIDAR ALEXIEV}

Institut du folklore de l'Académie bulgare des Sciences, Sofia 